This item was submitted to Loughborough's Research Repository by the author.

Items in Figshare are protected by copyright, with all rights reserved, unless otherwise indicated.

\title{
Selling and consuming the nation: understanding consumer nationalism
}

PLEASE CITE THE PUBLISHED VERSION

https://doi.org/10.1177/1469540517690570

PUBLISHER

SAGE (@ the authors)

VERSION

AM (Accepted Manuscript)

\section{PUBLISHER STATEMENT}

This work is made available according to the conditions of the Creative Commons Attribution-NonCommercialNoDerivatives 4.0 International (CC BY-NC-ND 4.0) licence. Full details of this licence are available at: https://creativecommons.org/licenses/by-nc-nd/4.0/

\section{LICENCE}

CC BY-NC-ND 4.0

\section{REPOSITORY RECORD}

Castello, Enric, and Sabina Mihelj. 2017. "Selling and Consuming the Nation: Understanding Consumer Nationalism". Loughborough University. https://hdl.handle.net/2134/23454. 
This is a pre-print version of the manuscript as accepted for publication in the Journal of Consumer Culture, Volume 17, forthcoming 2017

\title{
Selling and Consuming the Nation: Understanding Consumer Nationalism
}

\author{
Enric Castelló and Sabina Mihelj
}

\begin{abstract}
In recent years, nations have regained prominence as central symbols of political unity and mobilization, and proved capable of serving political goals across the political spectrum. Yet, the current revival of the national extends well beyond the realm of politics; it is anchored in the logic of global capitalism, and has become inextricably intertwined with the practices of promotion and consumption. Our article seeks to map the interface between nationalism and economic life, and bring some clarity to the so far fragmented debate on the topic, which developed under diverse headings such as "economic nationalism", "nation branding", "consumer ethnocentrism" and "commercial nationalism". We focus more closely on developing the concept of consumer nationalism, which received little sustained attention in cultural studies and in social sciences and humanities more generally. We offer a definition of consumer nationalism, situate it vis-à-vis the broader phenomena of economic nationalism and political consumerism, and propose an analytical distinction between political consumer nationalism and symbolic consumer nationalism. Drawing on existing literature we then consider a range of examples and examine how these two forms of consumer nationalism become involved in the reproduction of nationalism, taking into account both consciously nationalist discourses and practices as well as the more banal, everyday forms of nationalism.
\end{abstract}

Keywords: economic nationalism, commercial nationalism, consumer nationalism, consumer ethnocentrism, nation branding, everyday nationalism

As the Cold War came to an abrupt end, the changes brought by the intensification of global migration, cultural exchange and transnational political and economic cooperation seemed to demand a radical shift in the theoretical imagery used to make sense of the modern world. The examination of places, states and nations gave way to the exploration of the "space of flows", "networked connections" (Castells, 1996) and "non-places" (Augé, 1995); the study of societies was hastily replaced by the analysis of "mobilities" (Urry, 2000); and the investigation of national cultures gave primacy to the exploration of various de-territorialized "scapes" (Appadurai, 1996). Amidst these theoretical shifts, a few more cautious voices insisted on the continued vitality of nationalism, but argued that it now exists in a more diffuse, banal form embedded in taken-forgranted routines of everyday life (Billig, 1995; Fox and Miller-Idriss 2008), or has adapted in ways 
This is a pre-print version of the manuscript as accepted for publication in the Journal of Consumer Culture, Volume 17, forthcoming 2017

that made it more congruent with liberal democratic politics (Kymlicka, 2001).

More recently, a growing body of work stated looking at the articulations of nationalism beyond the realm of politics, and revealed a myriad of ways in which modern nations and nationalism are being sustained and revitalized through the workings of the global economy. Case studies of nation branding campaigns, consumer ethnocentrism and commercial nationalism from across the globe (Aronczyk, 2013; Lekakis, 2015; Volčič and Andrejevic, 2015; Wang, 2005) have by now amassed considerable evidence of the shifting forms of modern nations and nationalism in the context of global capitalism, and demonstrated that nationalism, far from being weakened by the world-wide spread of capitalist economy, became one of its indispensable building blocks.

While the recognition of the centrality of economy to the existence of nations and nationalism is not in itself new, the various manifestations of economic nationalism have only recently started attracting greater attention in their own right. Yet, despite this growing interest, the different aspects of economic nationalism have received rather uneven attention. By and large, the majority of literature is concerned with the "top-down" practices of nationalism, associated with state or commercial actors, rather than the "bottom-up" dynamics linked to individual consumers and everyday life. Although a body of work dealing with the interface between nationalism and consumer behaviour does exist, it hails primarily from business and marketing studies, while social sciences and humanities have so far had little to say on the topic. As a result, we know rather little about the cultural and social implications of economic nationalism in the context of everyday life that is, about what we propose to call consumer nationalism.

In this article we cannot do full justice to this lacuna, as this would require an extensive empirical investigation. Instead, we offer a conceptual and theoretical contribution to the debate, by seeking to develop a more coherent conceptualization of economic nationalism and its various 
This is a pre-print version of the manuscript as accepted for publication in the Journal of Consumer Culture, Volume 17, forthcoming 2017

manifestations, with a particular focus on consumer nationalism and its different forms. We first provide a mapping of recent literature examining the interface between economy and nationalism, noting its disciplinary fragmentation, main trends and omissions. We then outline our understanding of economic nationalism, and consumer nationalism and explain how it relates to political consumerism. We propose a distinction between two types of consumer nationalism - political and symbolic - and elaborate on each using a set of illustrative examples. We conclude by briefly reflecting on the relationship between consumer nationalism and the consumer practices associated with cosmopolitanism, arguing that consumer cosmopolitanism can coexist with, and often depends on, consumer nationalism.

\section{Mapping the field}

Broadly speaking, existing work in the area can be divided into three categories, which put emphasis on different key actors. Discussions of commercial and corporate nationalism typically focus on commercial and corporate entities and their use of nationalist discourse to promote particular goods and services. In contrast, debates about nation branding are primarily concerned with state-led efforts, usually in the form of promotional campaigns aimed at enhancing the image of the nation domestically or internationally in order to boost the national economy. Finally, literature centred on concepts such as ethnocentric consumption, ethnoconsumerism, consumer nationalism or consumer patriotism give primacy to the activities of consumers, examining how their practices relate to their sense of national belonging. As we shall show, these three areas have received uneven attention in existing literature.

Coined by the British brand consultant Simon Anholt in the late 1990s, the idea of nation branding is based on the assumption that the global popularity of consumer products is closely tied to the international reputation of nations that produce them. As Anholt (1998: p. 395) noted in one of the 
This is a pre-print version of the manuscript as accepted for publication in the Journal of Consumer Culture, Volume 17, forthcoming 2017

earliest pieces on nation branding, "most of the really successful international brands have come from countries that are successful brands in their own right, and substantial transfer of imagery and brand equity can often be seen to occur between the two". Since then, a wide range of work emerged aimed at generating guidance for states and other actors interested in harnessing the power of nationalism to boost their economies, as well as enhancing their image in the international arena (e.g., Anholt, 2006; Dinnie, 2010; Olins, 1999). In this sense, nation branding forms a branch of public diplomacy and partakes in the operations of soft power (Nye, 2004), with the chief difference lying in the means used to wield the power, which are no longer drawn from the traditional arsenal of international diplomacy, but from strategies developed by marketing consultants. As a result, as Bolin and Ståhlberg observe (2010: p. 96), contemporary nations "are marketed in the same way as companies are," with public bodies using corporate techniques in the drive to commodify the nation and use it to attract international investment and tourist revenue (Aronczyk, 2013: pp. 9-15).

More recently, nation branding and the associated use of soft power in the international arena has attracted attention among critically minded media and cultural studies scholars (Aronczyk, 2013; Kaneva, 2011; Thussu, 2013; Volčič, 2008). Rather than investigating the phenomenon with the aim to inform applied marketing and branding practice, this body of work focuses on reflecting on the political, social and cultural implications of nation branding. Aronczyk (2013) for instance examines the ways in which nation branding has affected our ideas of nationhood, citizenship and democratic communication, arguing that nation branding has come to be seen as a blanket solution for a variety of problems affecting societies in late modernity. Arguing along similar lines, Kaneva (2011) calls for a critical agenda in nation branding research, highlighting the incompatibility of branding principles with ideals of democracy, the tendency for nation branding to misrepresent and oversimplify the complexity of national cultures, and the fact that the practice of branding, rather than helping peripheral nations achieve greater visibility, ends up reproducing existing hierarchies of power in the world arena. 
This is a pre-print version of the manuscript as accepted for publication in the Journal of Consumer Culture, Volume 17, forthcoming 2017

While initially developed in relation to state-led initiatives, nation branding has rapidly evolved into a process that ties together a wide range of both political and commercial actors. In this sense, as Kania-Lundholm (2014) notes, a dual process is at work that involves a simultaneous nationalization of the commercial and the commercialization of the national; on the one hand, commercial entities use nationalism to sell goods and services, while states use marketing techniques to develop successful nation brands. This dual process is at the heart of what Volčič and Andrejevic (2015) refer to as "commercial nationalism", a term designed to encompass a broad range of phenomena that emerge when states and societies start envisioning themselves as corporations built to turn profit from their national culture.

In contrast to nation branding and commercial nationalism, consumer nationalism so far attracted relatively little attention in social sciences and humanities. In this respect, too, marketing and business studies specialists are leading the way. The concept of "consumer ethnocentrism" and the associated CETSCALE measure, proposed by Shimp and Sharma (1987), have become widely used in the field, and continue to be applied in a variety of cultural and political contexts (Bi et al., 2012; Netemeyer, Durvasula, and Lichtenstein, 1991; Lee, Hong, and Lee, 2003). In its original formulation, consumer ethnocentrism is used to refer to consumers' beliefs "about the appropriateness, indeed morality, of purchasing foreign-made products;" ethnocentric consumers thus believe that purchasing imported products should be avoided because "it hurts the domestic economy, causes loss of jobs, and is plainly unpatriotic" (Shimp and Sharma, 1987: p. 280).

While the concept of consumer ethnocentrism remains dominant, a smaller body of work prefers the concept of "consumer nationalism." Jay Wang (2005: pp. 223-224), for instance, uses it to refer to “consumers' invocation of collective identities based on their nationality to accept or reject products or brands from other countries." Unlike the literature on consumer ethnocentrism, studies of 
This is a pre-print version of the manuscript as accepted for publication in the Journal of Consumer Culture, Volume 17, forthcoming 2017

consumer nationalism tend to pay less attention to consumer beliefs, and focus instead on consumer practice and behaviour, especially those involving militant, politicized forms of consumer nationalism, aimed at using consumption as a means of inflicting economic and political damage on another nation (e.g., Ashenfelter, Ciccarella, and Howard, 2007; Cuadras and Raya, 2014; Fershtman and Gandal, 1998; Li, 2009). Similar consumer campaigns directed at domestic consumption have received less attention among marketing specialists, although the topic has been to some extent addressed by historians and anthropologists, who have studied various aspects of the interplay of consumption and nation in specific contexts, including the US (Frank, 1999), China (Gerth, 2003) and South Korea (Nelson, 2000).

Regardless of focus and disciplinary background, however, existing research on the role of consumers in the context of economic nationalism tends to privilege the more explicit, even virulent nationalist attitudes and practices. The definition of consumer nationalism provided by Karl Gerth (2011: p. 280) speaks for itself: consumer nationalism "refers to efforts to define buying and using (or consumption) as a political statement through the non-consumption of things from an offending country or countries and the consumption of one's own nationally produced goods and services." The attitudes and practices captured by this definition represent only one aspect of consumer nationalism the way we understand it here, and miss the more diffuse, mundane imbrications of consumption and nationalism such as the casual wearing of T-shirts with national symbols, the habit of choosing a national dish in a restaurant, or the routine, unremarkable buying of domestically produced goods in a local supermarket, which occur without any specific political agenda.

The failure to consider the mundane forms of consumer nationalism is underpinned by a narrow understanding of nationalism, which reduces the phenomenon to unambiguous expressions of nationalist fervour, or to what Michael Billig (1995) would call "hot nationalism." As a result, instances where commercial activities and consumption edge into the terrain of "banal nationalism" 
This is a pre-print version of the manuscript as accepted for publication in the Journal of Consumer Culture, Volume 17, forthcoming 2017

or "everyday nationhood" and form part of the mundane texture of everyday life have received little sustained attention (for an overview of rare studies that address this dimension see Fox and MillerIdriss 2008: 549-553). Yet, we contend that it is precisely these practices that play a crucial role in reproducing nationalism in the contemporary world. Without considering this more diffuse, less obviously nationalist practices, and understanding the way they relate to more overt forms of consumer nationalism, it is impossible to understand the continued vitality of nations and nationalism in the contemporary world.

\section{Consumer nationalism, economic nationalism and political consumerism}

Some of the most influential theories of nationalism are centrally concerned with the role of the economy in shaping modern nationalism, and even see economic factors as central to the historical rise of nationalism. According to Gellner (1983), for instance, the drive to establish culturally homogeneous nation-states was a direct effect of, and indeed a prerequisite for, the formation of modern industrialized economies, which required a common mass culture to enable individuals from all walks of life to participate in the standardized activities of industrial production. A similar argument about the necessary link between economic modernization and the rise of nationalism was advanced by Hechter (1975) and Nairn (1977), who sought the roots of nationalism in the global spread of capitalism, and more specifically in the web of economic dependency and colonial centreperiphery dynamics it created both between and within states.

While these arguments deserve revisiting, we should be wary of reducing nationalism to a mere side effect of economic transactions. As Mihelj argues (2011: 75-94), rather than adopting a monocausal explanation of nationalism, which privileges one set of explanations - economic, cultural, or political - over others, it is more productive to think of the different social factors as providing alternative routes to nationalism, which can become more or less prominent in different social and 
This is a pre-print version of the manuscript as accepted for publication in the Journal of Consumer Culture, Volume 17, forthcoming 2017

historical contexts. Judging from the already surveyed body of work, it can be argued that recent developments privilege the economic route to nationalism, meaning that nationalism is increasingly reproduced by means of institutions and practices attached to the economic realm: institutions such as corporations, retail chains, stock markets, media organizations, and practices involved in the exchange of goods and services, including advertising, branding, marketing, and consumption.

In line with this, we define economic nationalism, along with its constituent forms such as commercial and consumer nationalism, as a specific subtype of nationalism that gives primacy to economic practices (selling, advertising, consumption etc.) as key markers of nationhood. At the same time, economic nationalism also posits that the value and legitimacy of any institution, object or activity depends primarily on its contribution to the national economy. Following this logic, cultural and political institutions are forced to adopt the language and practices of the market; this process leads states, regional and local governments to behave as corporate actors that use the national brand to sell goods and services in order to boost the national economy, while cultural institutions endeavour to treat their products and services as goods designed to make profit for the nation. As an integral dimension of economic nationalism, consumer nationalism also gives primacy to economic activities as key markers of nationhood. More specifically, we can treat consumer nationalism as a set of discourses and practices that attach national significance to consumer objects (goods, services). These discourses and practices have individual consumers at their centre, but also involve commercial actors - retailers, advertisers, marketers, local producers etc. - who seek to reach the consumer using various discursive means, designed to instigate particular acts of consumption. These discursive means can take different communicative forms including adverts, packaging, product design and direct social interaction - and use a range of tools from explicit national symbols such as flags to more subtle references to national landscapes, landmarks or collective memories to link a particular good to the nation. Individual consumers become involved in consumer nationalism by engaging in acts of consumption of such nationalised 
This is a pre-print version of the manuscript as accepted for publication in the Journal of Consumer Culture, Volume 17, forthcoming 2017

goods, for instance by wearing a fashion product adorned with national symbols or colours, by consciously choosing to watch a domestically produced television show, or by mindlessly selecting a domestically produced item as part of the routine shopping experience.

Having explained how consumer nationalism relates to economic nationalism, we can now move on to examine its link with consumer culture and political consumerism. The understanding of consumption as a cultural practice, which is central to our definition of consumer nationalism, is of course nothing new; already in the late nineteenth century, Thorsten Veblen (1994[1899]) observed the use of consumption as a means of displaying one's social status among the nouveau riche, and the investigation of the cultural aspects of consumption also has a long tradition in anthropology (Douglas and Isherwood, 1979). In a related argument, Celia Lury (1996), relying on Bourdieu's notion of cultural distinction (1984), Lury also argued that consumption is an instrument of both identification and differentiation, a means by which individuals mark their relationship to particular social groups and their position in socially stratified societies (ibid.: p.186). Through the logic of differentiation and distinction, then, our consumer choices participate both in the construction of belonging and exclusion while at the same time tying us to the market economy, making culture and economic behaviour mutually constitutive of each other.

Given the association of consumption with spheres of leisure and private life, it is tempting to dismiss the intertwining of consumption and cultural belonging as a matter of little consequence to political life. Yet, as several authors have argued, the past few decades have seen a profound transformation of the nature of political life, which entailed a blurring of boundaries between public and private spaces and a growing political impact of informal and even semi-private forms of engagement, including those expressed through lifestyle choices and consumption (e.g., Inglehart, 1997; Norris, 2002). These transformations gave rise to what came to be known as political consumption, a form of political engagement that finds its expression in consumer behaviour and 
This is a pre-print version of the manuscript as accepted for publication in the Journal of Consumer Culture, Volume 17, forthcoming 2017

choices. Consumer politics has been defined as the practice of making consumer choices based on political and/or ethical considerations (Micheletti, Follesdal, and Stolle, 2003). Such choices can amount to more fully fledged forms of consumer activism, expressed through boycotts of specific products, which constitute an increasingly important part of political action, especially among young people (Stolle, Hooghe, and Micheletti, 2005). Forms of political consumerism of course vary, and Neilson (2010) draws a useful distinction between boycott, which implies punishing a given brand or product because of unfavourable behaviour by refusing to purchase it, and buycott, that consists of purposefully choosing services or brands of companies that follow ethically responsible or otherwise positive practices. In addition to these, political consumerism is also evident through cultural and discursive practices, such as the use of prominent brands in conjunction with particular discursive means and symbols to convey political messages (Stolle and Micheletti 2013: 170-203).

Consumer nationalism points to another way of distinguishing between different dimensions of political consumerism. If boycott, buycott, lifestyle politics and discursive political consumption capture the various means of expression used in consumer politics, consumer nationalism derives its specificity from its link with a particular kind of cultural identity (national identity) and discourse (nationalism) associated with it. To put it differently, consumer nationalism is a subtype of political consumerism that involves consumer choices driven by nationalist beliefs: it can serve as a means of expressing one's national belonging, of rejecting foreign nations etc. As such, consumer nationalism can be examined alongside other subtypes of political consumerism, which are motivated by other forms of cultural identity and associated discourses, such as religious consumerism of consumer cosmopolitanism.

Conceptualizing consumer nationalism in this way brings several benefits. First, it allows us to establish novel conceptual links between nationalism studies and the study of political consumption. 
This is a pre-print version of the manuscript as accepted for publication in the Journal of Consumer Culture, Volume 17, forthcoming 2017

On the pages that follow, we examine some of such links: among other things, we build on distinctions between boycott, buycott, lifestyle politics and discursive political consumption to develop a typology of consumer nationalism, and we also use the theory of banal or everyday nationalism to examine more or less "conscious" forms of consumer nationalism. Second, the focus on consumer nationalism brings to light the importance of cultural identity in the context of political consumption, and helps us reflect on how consumer politics linked to progressive, democratic and universalist causes relates to instances of political consumption motivated by particularist, exclusionary identifications. These questions received limited attention in existing literature. So far, debates on political consumerism have been drawn largely to examples of politically inflected consumer behaviour tied to politically progressive causes, such as fair trade, child labour, genre equity or forest conservation, and to campaigns with a global or cosmopolitan appeal which attract supporters regardless of cultural background (e.g. Stolle and Micheletti, 2013). In contrast, the more parochial forms of consumer politics, inspired by nationalist convictions, racism or religious fundamentalism, have received far less attention (for exceptions see e.g. Sand1kc1 and Ekici 2009, Swimberghe et al. 2011). Although issues of identity are often discussed in existing literature, this is done mostly in relation to individual self-expression in the context of post-industrial, postmaterialist societies (e.g. Micheletti, Follesdal and Stolle 2003) rather than in relation to (collective) cultural identity and associated discourses. As a result, we have little understanding of how political consumerism may vary depending on the different cultural identifications of consumers. Arguably, for instance, political consumption driven by nationalism is much more likely to adopt banal, everyday forms (as discussed further on in this paper) than political consumption motivated by more universalist causes, which require a more deliberate commitment. If we are to understand the full social, cultural and political implications of consumption, identity-related aspects of political consumption thus ought to receive closer attention. Consumer nationalism offers one particularly fruitful ground for such investigation, which can help us consider more systematically the link between consumer politics and cultural identity, investigate the full range of spatial planes 
This is a pre-print version of the manuscript as accepted for publication in the Journal of Consumer Culture, Volume 17, forthcoming 2017

on which it operates (local, national, regional, global), and the political and economic entities tied to them (from local municipalities and farmers' markets to nation-states, regional political entities such as the EU, or multinational corporations operating globally). Some of the issues worth considering in this context are addressed in the last section of this paper, where we discuss the relationship between consumer nationalism and consumer cosmopolitanism.

\section{Consumer nationalism: A typology}

The different acts and discourses of consumer nationalism stand in different relations to political and cultural dimensions of social life. Much as political consumerism, consumer nationalism can adopt forms that are explicitly political and linked to political entities, as well as forms that are primarily cultural or symbolic and tied for instance to lifestyle politics. To differentiate between them, we propose to distinguish between two ideal types of consumer nationalism: political consumer nationalism (PCN) and symbolic consumer nationalism (SCN). As we shall see from the examples that follow, both types of consumer nationalism rely on actions of individual consumers in the context of everyday life, but the first type (PCN) also requires a more or less explicit involvement of institutional actors, such as states, political parties or civil society groups. It is worth noting that this typology corresponds with different types of strategic approaches used by advertisers in their attempts to appeal to consumers using nationalist language (cf. Prideaux 2009), which suggests that our typology could also be used to differentiate between various forms of nationalism in advertising. We should also add that we do not consider these two types of consumer nationalism as mutually exclusive; concrete instances of nationalist consumer practices can, and often do, combine both political and symbolic dimensions. Another thing worth keeping in mind is that the discourses and practices of consumer nationalism, whether political or cultural, are rarely if ever consensual. Rather, they are marked by an ongoing contestation over what it means to belong to a nation. 
This is a pre-print version of the manuscript as accepted for publication in the Journal of Consumer Culture, Volume 17, forthcoming 2017

In what follows, we discuss each subtype using a range of brief illustrative examples, meant to provide a skeleton for subsequent, more in-depth and systematic research on the issue.

\section{$\underline{\text { Political consumer nationalism }}$}

We see political consumer nationalism (PCN) as a type of political consumerism that involves fostering or obstructing the consumption of particular national products with the aim of affecting a nation's economy and thereby promoting or attacking a particular nation politically as well. Note that culture is here mobilized to achieve a political goal, but using economic means. In this sense, PCN relies on what Holzer (2006) in his discussion of political consumerism defines as "role mobilization", namely the collectivization of your private choice in the moment of the purchase. The "role", in this case, consists of one's national belonging, which is used as a "transmission belt" for political objectives (ibid.: p. 406).

Building on Neilson (2010) we can distinguish between two sub-types of PCN, one consisting of nationalist boycotts that involve a refusal to purchase products tied to a particular nation, and the other covering nationalist buycotts that foster the buying of domestic goods at the expense of foreign goods in general. The political intentions of nationalist boycotts tend to be more immediately observable, as they usually arise in response to specific political actions of individual states. Nationalist boycotts of this kind received considerable attention among marketing and business studies specialists; examples include the Arab countries' boycott of Israeli cars (Fershtman and Gandal, 1998); US boycotts of French products (especially wine) during the Iraq war in 2003 in reaction to French opposition to military intervention (Ashenfelter, Ciccarella, and Howard, 2007); and the Spanish boycott of Catalan cava, which started in late 2004 in response to the declared intention of the Catalan Parliament to hold a referendum on independence (Cuadras and Raya, 
This is a pre-print version of the manuscript as accepted for publication in the Journal of Consumer Culture, Volume 17, forthcoming 2017 2014)

China, in particular, has a long history of using boycotts of foreign products as a political weapon, stretching from the boycotts of American and Japanese goods in the early $20^{\text {th }}$ century, provoked respectively by discrimination against Chinese workers in the US and the perceived lenience of Chinese authorities vis-à-vis Japanese demands, to more recent examples such as the 2008 boycott of the French chain Carrefour, prompted by the Paris attack on the Olympic torch relay in the runup to the Beijing Olympics and the alleged complicity of the French government and the media (Nyíri 2009, Orchard 1930). Recent examples awaiting analysis include the boycotting of German products since the Greek crisis, launched through social networks using hashtags such as \#BoycottGermany (BBC Trending, 2015).

The political implications of nationalist buycotts, on the other hand, may be more difficult to discern. Yet, if we take a closer look at the various "buy domestic" campaigns and related initiatives, we can quickly see that they are often supported or even explicitly launched by state agencies or political parties, or by economic actors and civil society organisations with particular political agendas. In Spain, for instance, the recent Moda España initiative was supported by the Ministries of Industry and Culture with the explicit aim to stimulate the production and consumption of fashion products made in Spain (Catasús and Riera, 2013), while the Chamber of Craft and Small Businesses in Slovenia launched the "Product of Slovenian Manufacturers" trademark with the aim of "informing consumers of Slovenian products", reducing unemployment in the sector, and stemming the influx of imported products of supposedly dubious quality (OZS 2015).

Where such political links are not immediately obvious, "buy domestic" and similar campaigns nonetheless make a more or less direct political statement, typically by aligning themselves with recognizably protectionist economic policies and attitudes, such as supporting domestic industry or 
This is a pre-print version of the manuscript as accepted for publication in the Journal of Consumer Culture, Volume 17, forthcoming 2017

the creation of domestic jobs. Such is the case of the Buy British directory, the self-proclaimed "fastest growing online directory of British goods, products and services," which appeals to on-line visitors with the slogan "Advertise here - support British jobs, industry and promote your services" and offers readers a mix of news about economic developments as well as political events such as the 2013 Falklands Islands referendum (Buy British, 2015). While aimed primarily at companies rather than individual consumers, the Buy British directory of course partakes in the realm of commercial rather than consumer nationalism, but nonetheless relies on the language that appeals generally to consumers as well, enlisting individual consumer preferences in the battle for the British economy. A similar blend of politics and economy, consumer and commercial nationalism, can be found in the Made in Spain initiative designed to support Spanish products and companies, (Eticae Marcas Españolas 2015) or for Greek products (Lekakis, 2015).

As evident from the examples listed here, the institutional and organizational infrastructures of PCN can vary considerably. While many instances of PCN are initiated by state institutions, others are promoted by political parties, and yet others by economic entities, non-governmental and civil society groups. It is possible that the organizational infrastructure of such events varies depending on the political context and the established traditions of political action - an issue that would deserve further examination.

\section{$\underline{\text { Symbolic consumer nationalism }}$}

In contrast to PCN, symbolic consumer nationalism (SCN) draws attention to discourses and practices oriented chiefly to cultural rather than political ends and, more specifically, to the reproduction of nationalism by means of consuming, using, buying or wearing products or services that are either produced nationally or otherwise recognized as national. Much as the forms of political consumerism involving lifestyle choices guided by ethical convictions or environmental 
This is a pre-print version of the manuscript as accepted for publication in the Journal of Consumer Culture, Volume 17, forthcoming 2017

concerns, SCN involves economic activities that are less obviously political and can be seen as belonging primarily to the realm of culture (even though they, too, have political implications). This type of consumer nationalism can arise in relation to services such as those provided by an airline company or a bank; in conjunction with material commodities such as food, drinks, fashion clothing, electronic goods or cars; or in association with cultural products such as music, literature, television programs or film. This aspect of consumption has been researched in relation to ethnic minorities, but much less so in relation to national majorities.

SCN can take many forms, ranging from explicit, conscious acts of wearing a T-shirt with a national flag to the more mundane, unreflective shopping preferences. As Edensor (2002: p. 88) argues, nationhood is in part constituted through mundane performances that are not necessarily recognized as national, but are "shaped by unreflexive assumptions and dispositions [...] revealing kinds of habitus that evolve within a national field." It is in this context, at the intersection of unreflexive and reflexive activities, that we should situate symbolic consumer nationalism. Shopping, and consumption more generally, often consists of activities which, despite being performed in a mindless manner, contribute to the reproduction of nationalism. The national patterns of everyday shopping are rarely recognized, and become more clearly evident only once we move outside of our everyday, nationwide retail environments, and move to other regions and countries; or when our domestic environments become suddenly disrupted by shortages of supply or changes in the offer and branding of products (Edensor 2002: pp. 109-111). When appearing in such an unreflexive mode, symbolic nationalist consumption forms part of the banal, everyday reproduction of nationalism (Billig 1995, Fox and Miller-Idriss 2008) engrained in the taken-forgranted habits and routines we no longer recognize as specifically national.

It is important to note that SCN is not limited to the consumption of domestically produced goods and services, but can also arise in response to imported commodities, including items that may 
This is a pre-print version of the manuscript as accepted for publication in the Journal of Consumer Culture, Volume 17, forthcoming 2017

otherwise be seen as thoroughly global. As Foster (2002: pp. 63-127) shows in his study of nationmaking in Papua New Guinea, individual ownership or consumption of goods that are seen as parts of national culture form a powerful means of nation-building not only when it comes to local commodities such as rice and betel nut, but also in relation to global products such as Coca-Cola. These imbrications of the national and the global in consumption processes become even more pronounced when global corporations themselves incorporate the national at various levels of production and distribution. In this context it is not a surprise that Toyota cars can be marketed to British consumers as distinctly British, as is the case with the new Avensis, a British-built car manufactured exclusively at the Toyota car plant in the English Midlands. Far from becoming displaced by the globalization of commodity markets, $\mathrm{SCN}$ thus continues to play a central role in the transnational flows of goods and services, acting as a mediator that ties products that could otherwise be perceived as foreign to localized practices of nation-making.

Another common example of SCN involves wearing clothing products or accessories with national symbols like flags or other emblems. The shop Vambcats.com (2015), for instance, offers a wide range of sport shoes with the Catalan self-determination flag and symbols. On the Catalan national day in 2015 the shop promoted a special offer including a pair of sports shoes, the independentist flag and free transport. In such a context, consumer goods such as a pair of sneakers can become a fashionable political product with a national distinction.

Consuming a national product or a product adorned with a national symbol can of course mean many things, depending on the background of the consumer and the context of consumption. Wearing a T-shirt with a US flag in the UK, for instance, will conjure up very different meanings than wearing a T-shirt with a Kosovo flag in Serbia. The possible meanings attached to national consumer products and activities are particularly complex in the context of multi-national states such as Britain and Spain. The act of buying a hamburger at a stall adorned with the Union Jack and 
This is a pre-print version of the manuscript as accepted for publication in the Journal of Consumer Culture, Volume 17, forthcoming 2017

owned by the "British Food Company" will clearly signal different things depending on whether the stall is located in Scotland or the English Midlands. To put it differently, consumer nationalism and SCN, in particular - is a communicative act, and as such subject to divergent interpretations at the different moments in the communication cycle: the product designer who chooses to adorn a commodity with national colours may do that for reasons that can be very different from those that prompt a consumer to buy the same product. A British farmer, for instance, may decide to join the "buy domestic" campaign and label his products as Made in Britain out of a genuine attachment to his homeland, or out of pragmatic commercial considerations. Likewise, a shopper may decide to choose a bag of apples adorned with a British flag out of a nationalist motivation, or because she thinks the fruit is likely to taste better if it travelled fewer miles. Further research is needed to discern the patterns of meanings enacted through processes of nationalist consumption, unpack the social and economic factors that shape them, and understand the manifold aims they serve.

The potential for multiple interpretations and ambivalence is sometimes engrained in the marketing strategies. This is evident when examining products labelled with unofficial national emblems such as the Shamrock for Irish products, the bull for Spanish products or the American eagle for U.S. products. To illustrate this, Sawchuck and Crow (2009) studied how companies use the Canadian beaver icon in the context of advertising, noting the different ways in which it is used to represented the Canadian identity. Such multivalent national symbols offer a particularly efficient way of appealing to diverse audiences who may decide to purchase national products for a variety of different reasons.

It is also worth noting that the ways in which consumers engage with or even recognise the national symbolism of their consumer choices can depend on their cultural as well as economic capital. Arguably, not all consumers have access to information that would allow them to unpack the national symbolism of products or reflect on either its economic motivations or political 
This is a pre-print version of the manuscript as accepted for publication in the Journal of Consumer Culture, Volume 17, forthcoming 2017

consequences. Furthermore, the ability to consciously invest in consumer nationalism will also be restricted by the individual's socio-economic standing and her or his access to goods more generally. Finally, even when an individual consumer is both willing and able to invest in national products, there will likely be a limit to how much he or she is prepared to pay.

\section{By way of conclusion: Consumer nationalism and beyond}

To conclude, let us briefly address one possible objection to the analysis we have developed so far namely, that the consumption of products marketed as national is not necessarily an expression of nationalism, but could be seen as a marker of cosmopolitanism or transnationalism. Or, as Fox and Miller-Idriss (2008: 552) put it: "while nationally minded consumers give expression to their national sensibilities through the consumption and display of their 'own national' artefacts, others consume the same artefacts, rechristened 'world culture', to demonstrate and perform their (ostensible) cosmopolitanism".

In the world of global migration, tourism and cross-border flows of culture and media, the consumption of "national" goods and services from across the world has become near-ubiquitous, and forms part of a varied cultural diet that seems to defy the national order of things. Indeed, the consumption of foreign goods and culture is often taken as one of the indices of cosmopolitanism, and has been found to align with stronger supranational identifications (e.g. Rössel and Schroedter, 2013; Woodward et al., 2008). According to Beck (2002), such cosmopolitan consumer practices are becoming increasingly widespread and taken for granted, and amount to a form of "banal cosmopolitanism" that, in his view, "appears to be displacing banal nationalism" (p. 28).

Yet, we should be wary of interpreting such consumption of foreign goods as evidence of the subversion or even eclipse of consumer nationalism. We should acknowledge that the consumption 
This is a pre-print version of the manuscript as accepted for publication in the Journal of Consumer Culture, Volume 17, forthcoming 2017

of foreign goods is itself premised on the existence of a world of nations and national products, rather than offering a fundamental challenge to it. This tight relationship between the national and the global is inherent in the very logic of national imagination. As Foster (2002: p. 11) notes, imagining the nation always entails imagining a world of nations, and an awareness of how things are done among other nations. National consumer goods and nation brands are no exception: to appeal to consumers globally - including those that feel a stronger attachment to global rather than national communities - they need to adopt a shared language, and that language remains a language of nations.

Furthermore, as empirical research that investigates the consumption of both domestic and foreign goods shows (Bennett et al., 2009; Meuleman, 2014; Meuleman and Savage, 2013; Savage et al., 2010; Smith and Phillips, 2006) the consumption of imported goods is itself shaped by a particular context in which it occurs, and is, in that sense, profoundly national. A British citizen consuming an Indian takeaway in London may superficially seem to be engaged in an act of banal cosmopolitanism, yet given that Indian cuisine in Britain forms part of the country's colonial heritage this act is more adequately interpreted as part of consumer nationalism. As Savage et al. (2010: p. 614) point out, "we need to recognize that the proliferation of cultural flows is highly uneven across the globe and tends to be based on the well-known principle of 'homophily' - that is to say they connect territories that are seen as being populated by 'people like us'. These results suggest that while transcending the traditional bounds of the national, some forms of transnational consumption may in fact go hand in hand with forms of particularistic belonging and exclusion, both old and new. Also worth noting is that the consumption of foreign goods does not necessarily go at the expense of the consumption of national goods; the appreciation of the domestic and the foreign can easily coexist (e.g. Meuleman and Savage, 2013: p. 253).

Another argument against embracing transnational consumption as a clear-cut (or perhaps even 
This is a pre-print version of the manuscript as accepted for publication in the Journal of Consumer Culture, Volume 17, forthcoming 2017

progressive) alternative to consumer nationalism is its close tie with socio-economic status. A range of studies so far have confirmed that the consumption of foreign goods functions as a prominent marker of social distinction, and is in the process of replacing the traditional cultural markers tied to the consumption of high-brow culture (Meuleman, 2014; Rössel and Schroedter, 2015). Meuleman (2014: p. 135), for instance, reports a negative association between educational level and domestic cultural consumption found in thirty countries from different continents. More specifically, the consumption of foreign goods and culture appears determined by different forms of cultural capital, and can therefore be interpreted "as a form of class-based practice" (Rössel and Schroedter, 2015: 80). In this sense, as Meuleman and Savange argued (2013: p. 231) "cosmopolitan currents do not simply erode national boundaries, but may actually create new stakes which differentiate within nations." Taking these arguments into account we can argue that consumer nationalism and consumer "cosmopolitanism," while seemingly pulling in opposite directions, are in fact working in tandem to reproduce a form of belonging perfectly adjusted to the workings of global capitalism. Along with other manifestation of economic nationalism, consumer nationalism channels expressions of national belonging through the realm of economy, marginalizing forms of nationhood that center on traditional forms of citizen engagement and the political institutions of nation-states. In its own way, transnational consumption likewise encourages us to restrict our public engagement to the realm of consumption, while leading us to believe that it offers an enlightened alternative to the seemingly parochial practices and preferences of our compatriots.

As with other forms of nationalism, we should therefore be wary of passing hasty judgements when it comes to consumer nationalism. As Calhoun (2007) reminds us, nationalism is a Janus-faced phenomenon; although often aligned with anti-democratic impulses, it is also capable of fostering inclusion, equality and acceptance of diversity. A similar argument applies to consumer nationalism. On the one hand, it can have the effect of limiting the scope of democratic engagement, enclosing citizenship empowerment in the realm of everyday consumption, and reproducing parochial 
This is a pre-print version of the manuscript as accepted for publication in the Journal of Consumer Culture, Volume 17, forthcoming 2017

thinking and exclusion. On the other hand, however, it can also be used strategically to revitalize local economies and communities, limit the environmental costs of long-distance trade, and engender a sense of empowerment among individuals and communities that may otherwise feel alienated from traditional instruments of political engagement. If we are to understand the workings of nationalism in the world of global capitalism, we should therefore take care to acknowledge both its positive and its negative implications.

\section{References}

Anholt S (1998) Nation-brands of the Twenty-first Century. Journal of Brand Management 5(6): 395-406.

Anholt S (2006) Competitive Identity: The New Brand Management for Nations, Cities and Regions. Basingstoke: Palgrave Macmillan.

Appadurai A (1996) Modernity at Large: Cultural Dimensions of Globalisation, Minneapolis: University of Minnesota Press.

Aronczyk M (2013) Branding the Nation. The Global Business of National Identity. New York: Oxford University Press.

Ashenfelter O, Ciccarella S, and Howard JS (2007) French Wine and the U.S. Boycott of 2003: Does Politics Really Affect Commerce? Journal of Wine Economics 2(1): 55-74.

Augé M (1995) Non-places: An Introduction to Supermodernity. London: Verso. 
This is a pre-print version of the manuscript as accepted for publication in the Journal of Consumer Culture, Volume 17, forthcoming 2017

BBC Trending (2015) Who is Calling to People to 'Boycott Germany'? BBC News on-line, July 15. http://www.bbc.co.uk/news/blogs-trending-33538098

Beck U (2002) The Cosmopolitan Society and its Enemies. Theory, Culture \& Society, 19(1-2): 1744.

Benkler Y (2006) The Wealth of Networks. How Social Production Transforms Markets and Freedom. New Haven and London: Yale University Press.

Bennett T, Savage M, Silva E, Warde A, Gayo-Cal M and Wright D (2009) Culture, Class, Distinction. London: Routledge.

Bi X, Gunessee S, Hoffmann R, Hui W, Larner J, Ma QP and Thompson FM (2012) Chinese Consumer Ethnocentrism: A Field Experiment, Journal of Consumer Behaviour 11(3): 252263.

Billig M (1995) Banal Nationalism. London-Thousand Oaks-New York: Sage.

Bloomberg (2013) China's Media Condemns Abe as Boycott Calls Grow on Weibo. Bloomberg News. December 28. http://www.bloomberg.com/news/articles/2013-12-27/china-s-state$\underline{\text { media-condemns-abe-visit-amid-calls-for-boycott }}$

Bolin G and Ståhlberg P (2010) Between Community and Commodity. Nationalism and Nation Branding”. In: Roosvall A and Salovaara-Moring I (eds) Communicating the Nation. National Topographies of Global Media Landscapes. Göteborg: Nordicom-Göteborg University, pp. 79-101. 
This is a pre-print version of the manuscript as accepted for publication in the Journal of Consumer Culture, Volume 17, forthcoming 2017

Bourdieu P (1984) Distinction. A Social Critique of the Judgement of Taste. Cambridge, MA: Harvard University Press.

Buy British (2015) Buy British. http://www.buybritish.co.uk/ (accessed June 10, 2015).

Calhoun C (2009) Nationalism and Cultures of Democracy. Public Culture 19(2): 151-174.

Castells M (1996) The Rise of the Network Society. Cambridge, MA: Blackwell.

Catasús JF and Riera S (2013) Moda España impulsa la campaña MÑ para realzar el "Made in Spain" entre los consumidores. Modaes.es. http://www.modaes.es/back-stage/20130430/modaespana-impulsa-la-campana-mn-para-realzar-el-made-in-spain-entre-los-consumidores.html.

Chernilo D (2015) Las relaciones entre nacionalismo y cosmopolitismo. Papers. Revista de Sociología, 100(3): 303-324.

Clarke DB (2003) The Consumer Society and the Postmodern City. London: Routledge.

Cuadras X and Raya JM (2014) Boycott or Buycott? Internal politics and consumer choices. Universitat Pompeu Fabra. Barcelona. http://repositori.upf.edu/handle/10230/22666 (accessed July 29, 2015).

Dinnie K (2008) Nation branding. Concepts, Issues, Practice. Oxford: Elsevier.

Douglas M and Isherwood B (1979) The World of Goods. Towards an Anthropology of 
This is a pre-print version of the manuscript as accepted for publication in the Journal of Consumer Culture, Volume 17, forthcoming 2017

Consumption. New York: Basic Books.

Edensor T (2002) National Identity, Popular Culture and Everyday Life. Oxford and New York: Berg.

Eticae Marcas Españolas (2015) Made in Spain - Fabricado en España. http://www.madeinspain.es/hecho-en-espana, (accessed July 29, 2015).

Fershtman C and Gandal N (1998) The Effect of the Arab Boycott on Israel: The Automobile Market. The RAND Journal of Economics 29, no 1: 193-214.

Foster RJ (2002) Materializing the Nation: Commodities, Consumption and Media in Papua New Guinea. Bloomington, IN: Indiana University Press.

Fox J and Miller-Idris C (2008) Everyday Nationhood. Ethnicities 8(4): 536-576.

Frank D (1999) Buy American : the Untold Story of Economic Nationalism. Boston, MA: Beacon Press.

Gellner E (1983) Nations and Nationalism. London: Basil Blackwell.

Gerth K (2003) China made. Consumer Culture and the Creation of the Nation. Cambridge, MA, and London: Harvard University Press.

Gerth K (2011) Consumer Nationalism. In: Southerton D (ed.) Encyclopedia of Consumer Culture, London: Sage, pp. 280-282. 
This is a pre-print version of the manuscript as accepted for publication in the Journal of Consumer Culture, Volume 17, forthcoming 2017

Hechter M (1975) Internal Colonialisms: The Celtic Fringe in British National Development, 15361966. Berkeley, CA: California University Press.

Holzer B (2006) Political Consumerism between Individual Choice and Collective Action: Social Movements, Role Mobilization and Signalling. International Journal of Consumer Studies, 30(5): 405-415.

Inglehart R (1997) Modernization and Posmodernization: Cultural, Economic and Political Change in 43 societies. Princeton, NJ: Princeton University Press.

Kaneva N (2011) Nation Branding: Toward and Agenda for Critical Research, International Journal of Communication 5: 117-141.

Kania-Lundholm M (2014) Nation in Market Times: Connecting the National and the Commercial: A Research Overview. Sociology Compass 8(6): 603-613.

Kymlicka W (2001) Politics in the Vernacular. Nationalism, Multiculturalism and Citizenship. New York: Oxford University Press.

Lee WN, Hong JY and Lee SJ (2003) Communicating with American Consumers in the Post 9/11 Climate: An Empirical Investigation of Consumer Ethnocentrism in the United States. International Journal of Advertising 22(4): 487-510.

Lekakis E (2015) Economic nationalism and the cultural politics of consumption under austerity: The rise of ethnocentric consumption in Greece. Journal of Consumer Culture. First published 
This is a pre-print version of the manuscript as accepted for publication in the Journal of Consumer Culture, Volume 17, forthcoming 2017

on June 12, 2015 as doi:10.1177/1469540515586872.

Li H (2009) Marketing Japanese Products in the Context of Chinese Nationalism. Critical Studies in Media Communication, 26(5): 435-456.

Lury C (1996) Consumer Culture. New Brunswick, NJ: Rutgers University Press.

Meuleman R (2014) Consuming the Nation: Domestic Cultural Consumption, its Stratification and Relation with Nationalist Attitudes. Groningen and Utrecht: ICS Dissertation Series.

Meuleman R and Savage M (2013) A Field Analysis of Cosmopolitan Taste: Lessons from the Netherlands. Cultural Sociology 7(2): 230-256.

Micheletti M, Follesdal A and Stolle D (2003). Politics, Products, and Markets: Exploring Political Consumerism Past and Present. New Brunswick, NJ: Transaction Press.

Mihelj S (2011) Media Nations. Communicating Belonging and Exclusion in the Modern World. Basingstoke and New York: Palgrave McMillan.

Nairn T (1977) The Break-up of Britain: Crisis and Neo-Nationalism. London: New Left Books.

Neilson LA (2010) Boycott or Buycott? Understanding Political Consumerism. Journal of Consumer Behaviour, 9(3): 214-227.

Nelson LC (2000) Measured Excess. Status, Gender, and Consumer Nationalism in South Korea. New York: Columbia University Press. 
This is a pre-print version of the manuscript as accepted for publication in the Journal of Consumer Culture, Volume 17, forthcoming 2017

Norris P (2002) Democratic Phoenix: Reinventing Political Activism. Cambridge: Cambridge University Press.

Netemeyer RG, Durvasula S and Lichtenstein DR (1991) A Cross-National Assessment of the Reliability and Validity of the CETSCALE. Journal of Marketing Research 28(3): 320-327.

Nye JS (2004) Soft Power. The Means to Power in World Politics. New York: Public Affairs.

Nyíri P (2009) From Starbucks to Carrefour: Consumer Boycotts, Nationalism and Taste in Contemporary China, PORTAL: Journal of Multidisciplinary International Studies 6(2): 1-25.

Olins W (1999) Trading Identities: Why Countries and Companies are Taking Each Other's Roles. London: Foreign Policy Centre.

Orchard, DJ (1930) China's Use of the Boycott as a Political Weapon, The Annals of the American Academy of Political and Social Science 152: 252-261.

OZS (2015) Blagovina znamka “Izdelek slovenske obrti”, http://www.ozs.si/Za\%C4\%8Dlane/Sekcijeinodbori/Sekcijatekstilcev/BlagovnaznamkaIzdelek slovenskeobrti.aspx (accessed July 29, 2015).

Prideaux J (2009) Consuming icons: Nationalism and Advertising in Australia. Nations and Nationalism, 15(4): 616-635.

Sandıkcı, Ö and Ekici A (2009) Consumerism and Identity, Journal of Business Research 62(2): 
This is a pre-print version of the manuscript as accepted for publication in the Journal of Consumer Culture, Volume 17, forthcoming 2017

208-217.

Savage M, Wright D and Gayo-Cal M (2010) Cosmopolitan Nationalism and the Cultural Reach of the White British. Nations and Nationalism 16(4): 598-615.

Sawchuck K and Crow B (2009) Leave it to the Beavers: Animals, Icons and the Marketing of the Bell Beavers. In: Castelló E, Dhoest A, O’Donnell H (eds.) The Nation on Screen. Discourses of the National on Global Television. Newcastle upon Tyne: Cambridge Scholars Publishing, pp. 309-325.

Shimp TA and Sharma S (1987) Consumer Ethnocentrism: Construction and Validation of the CETSCALE. Journal of Marketing Research 24(3): 280-289.

Smith P and Phillips T (2006) Collective Belonging and Mass Media Consumption: Unraveling how Technological Medium and Cultural Genre Shame the National Imaginings of Australians, The Sociological Review 54(4): 818-846.

Stolle D, Hooghe M and Micheletti M (2005) Politics in the Supermarket: Political Consumerism as a Form of Political Participation. International Political Science Review/ Revue Internationale de Science Politique, 26(3): 245-269.

Stolle D and Micheletti M (2013) Political Consumerism: Global Responsibility in Action. Cambridge: Cambridge University Press.

Swimberghe K, Flurry LA, and Parker JM (2011) Consumer Religiosity: Consequences for 
This is a pre-print version of the manuscript as accepted for publication in the Journal of Consumer Culture, Volume 17, forthcoming 2017

Consumer Activism in the United States. Journal of Business Ethnics 103(3): 453-467.

Thussu DK (2013) Communicating India's Soft Power: Buddha to Bollywood, Basingstoke:

Palgrave Macmillan.

Urry J (2000) Sociology Beyond Societies, London: Routledge.

Veblen T (1994) The Theory of the Leisure Class: An Economic Study in the Evolution of Institutions. New York: Penguin Books.

Venkatesh A (1995) Ethnoconsumerism: A new paradigm to study cultural and cross-cultural consumer behavior. In: Costa JA and Bamossi G (eds.) Marketing in the multicultural world, London, New York and Thousand Oaks, CA: Sage Publications, pp. 26-67.

Volčič Z (2008) Former Yugoslavia on the World Wide Web: Commercialization and Branding of Nation-States. The International Communication Gazette 70(5): 395-413.

Volčič Z and Andrejevic M (2015, in press) Commercial Nationalism: Selling the Nation and Nationalizing the Sell. Basingstoke: Palgrave.

Vamcats.cats (2015) http://www.vamcats.cat/content/12-origen (accessed July 29, 2015).

Wang J (2005) Consumer Nationalism and Corporate Reputation Management in the Global Era. Corporate Communications: An International Journal, 10(3): 223-239. 